\title{
特集：皮膚の臨床免疫
}

総 説

皮膚のリンパ腫とケモカイン

菅谷誠

\section{Cutaneous lymphoma and chemokine}

\author{
Makoto Sugaya, M.D., Ph.D. \\ Department of Dermatology, Faculty of Medicine, University of Tokyo
}

(Received January 7, 2011)

\begin{abstract}
summary
The expression pattern of chemokines and chemokine receptors is specific to certain organs and cells. Therefore, chemokines are important to elucidate the mechanism of organ-specific human diseases such as cutaneous lymphoma, characterized by proliferation of clonally expanded lymphocytes in skin without detectable systemic involvement. The most popular type of cutaneous lymphoma is T cell lymphoma, including mycosis fungoides and Sezary syndrome. We have reported that CCL17, CCL27, CCL11, and CCL26 are involved in progression of these diseases. The above chemokines are highly expressed in the lesional skin and serum levels of the chemokines are elevated as the disease progressed. Moreover, CXCL9 and CXCL10 are associated with epidermotropism of tumor cells, CCL21 is important for tumor invasion to lymph nodes, and CXCL12 may explain downregulation of CD26 on the cell surface. CXCL13 expression in lymphoid follicular formation in skin and CCR3 expression on tumor cells in CD30 ${ }^{+}$lymphoproliferative disorders are also discussed. Biologics targeting chemokines and their receptors are promising strategies for cutaneous lymphoma. Indeed, humanized anti-CCR4 monoclonal antibody showed potent antitumor activity against CCR4 ${ }^{+}$ lymphoma cells both in vitro and ex vivo. This antibody may also be useful for allergic diseases such as hay fever. Further study on chemokines and chemokine receptors will be helpful for new classification of cutaneous lymphoma, elucidation of pathogenesis, and development of new therapeutic strategies.
\end{abstract}

Key words — mycosis fungoides; Sezary syndrome; CCL17; CCL27; CCL11

抄録

ケモカインとその受容体は，特定の臓器や細胞集団に発現する．皮膚のリンパ腫は腫瘍細胞が皮膚という特定の 臓器に限局することから，ケモカインがその病態に関与していることが考えられる．皮膚のリンパ腫の代表的な疾 患である菌状息肉症・セザリ一症候群に拈いて，CCL17，CCL27，CCL11，CCL26などのケモカインが病態に関 与していることを，これまで我々は報告してきた。これらは皮膚病変部で発現しているだけでなく，血清中でも正 常人と比べて上昇して抢，病勢マーカーとして有用である。また CXCL9，CXCL10 は表皮向性，CCL21 はリ ンパ節への浸潤，CXCL12 は腫瘍細胞の CD26 発現低下と関係していることが知られている．さらにCXCL13 は 皮膚への B 細胞の浸潤，CCR3 は CD30 陽性リンパ増殖症との関与が考えられている. CCR4 を治療のターゲット とした抗体療法が， CCR4 陽性 T 細胞リンパ腫とアレルギー性疾患に対して開発されつつあり，今後もケモカイン と受容体に関する研究よってリンパ腫の分類や病態解明，新しい治療の開発が進むことが期待される.

\section{はじめに}

原発性皮膚リンパ腫とは，診断確定時に皮膚以外 の臓器に病変を認めないリンパ腫である。その大部 分は $\mathrm{T}$ 細胞が腫瘍化した皮膚 $\mathrm{T}$ 細胞リンパ腫であ るが，B 細胞や NK 細胞のリンパ腫も存在する．表

東京大学医学部 皮膚科
1 に 2008 年に発表された WHO（World Health Organization）分類に抢ける原発性皮膚リンパ腫の各 疾患カテゴリーを示す1). 治療法や予後は腫瘍細胞 の種類や浸潤形態などで異なるが，診断確定後数年 以内に患者が死亡するケースもあり, 病態解明, 治 療法の開発が急がれる疾患である．皮膚のリンパ腫 は，病初期は皮膚においてのみリンパ腫細胞が増殖 するという特異な疾患である.リンパ球は脾蔵，リ 
表 1 原発性皮膚リンパ腫の WHO 分類（2008 年）

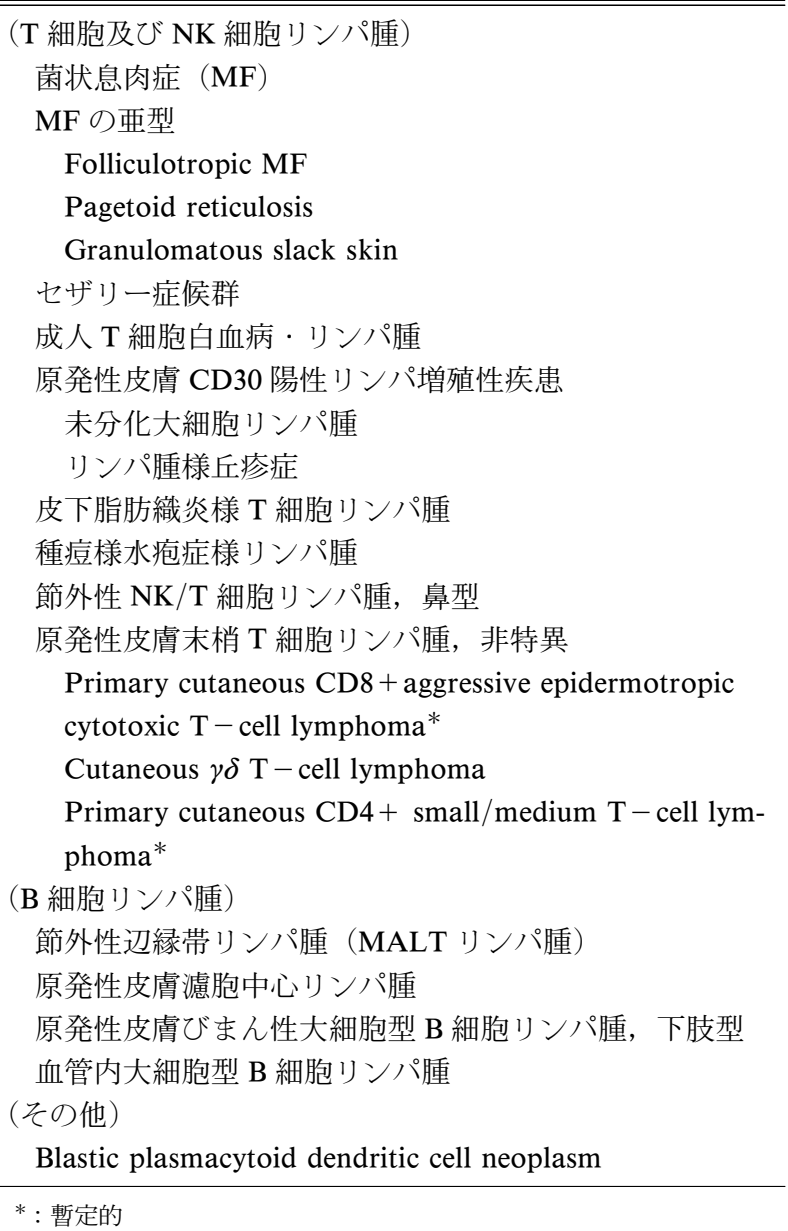

ンパ節といったリンパ組織の他, あらゆる臓器に血 管,リンパ管を介して環流し，全身の免疫を担って いる. 従って，何故リンパ腫細胞が皮膚という特定 の臓器にのみ限局して存在するのか，そのメカニズ ムを知ることはこの疾患の病態を理解することに繋 がり, 治療に結びつく重要な問題である.

近年，リンパ球表面に発現する接着分子やケモカ イン受容体がリンパ球の遊走する臓器を規定するこ とが明らかとなり，非常に注目を浴びている．例え ば接着分子の一つである皮膚リンパ球関連抗原 (cutaneous lymphocyte-associated antigen; CLA) は皮膚に浸潤してくるリンパ球に発現していること が知られており，アトピー性皮膚炎などの炎症性皮 膚疾患に抢いて病変部に陽性細胞が多数観察され る。またケモカイン受容体である CCR4 や CCR10 は CLA 陽性の皮膚特異的 $\mathrm{T}$ 細胞に発現しており, アトピー性皮膚炎などの炎症性皮膚疾患に打いて病 変部に陽性細胞が観察される。 また炎症性疾患のみ ならず，皮膚悪性リンパ腫の大部分を占める皮膚 T 細胞リンパ腫では, 腫瘍細胞は CLA, CCR4,
表 2 皮膚リンパ腫との関与が報告されているケモカイン

\begin{tabular}{|c|c|c|c|}
\hline ケモカ & 受容体 & $\begin{array}{c}\text { 想定されている } \\
\text { 機能 } \\
\end{array}$ & 文 献 \\
\hline CXCL13 & CXCR5 & B 細胞の浸潤 & $12), 13)$ \\
\hline $\begin{array}{l}\text { CXCL9, } \\
10\end{array}$ & CXCR3 & 表皮向性 & $2), 3), 14)-19)$ \\
\hline CCL17 & CCR4 & $\begin{array}{l}\text { 腫瘍細胞の皮膚浸 } \\
\text { 潤 }\end{array}$ & $\begin{array}{l}\text { 2)-6), 20), 21), } \\
27)\end{array}$ \\
\hline CCL27 & CCR10 & $\begin{array}{l}\text { 腫瘍細胞の皮膚浸 } \\
\text { 潤 }\end{array}$ & $5)-7), 26), 27)$ \\
\hline CXCL12 & CXCR4 & $\begin{array}{l}\text { 腫瘍細胞の皮膚浸 } \\
\text { 潤 }\end{array}$ & $16), 23)$ \\
\hline \multirow{2}{*}{$\begin{array}{l}\text { CCL11, } \\
26\end{array}$} & \multirow[t]{2}{*}{ CCR3 } & Th2 優位の環境 & 32) \\
\hline & & $\begin{array}{l}\text { ALCL のオートク } \\
\text { ライン }\end{array}$ & 34) \\
\hline CCL21 & CCR7 & リンパ節への浸潤 & $5), 6), 16)$ \\
\hline
\end{tabular}

CCR10 が陽性であることが示されている2 7)．こ のことは皮膚 $\mathrm{T}$ 細胞リンパ腫に抢いては，もとも と皮虐に親和性の高い $\mathrm{T}$ 細胞が腫瘍化しているこ とを示唆している．本稿では皮膚のリンパ腫の病態 について，皮膚 $\mathrm{T}$ 細胞リンパ腫を中心に，ヶモカ インの観点から解説する.

\section{ケモカインとは}

ケモカインは分子量 $10 \mathrm{kDa}$ 程度の蛋白質であ り, 特定の白血球サブセットの遊走作用・活性化を 支配するサイトカインとして発見された。近年では 遊走作用だけでなく, 細胞接着やアポトーシスの抑 制など様々な機能を有することが分かってきている. $\mathrm{N}$ 末端のシステイン残基の配列によって CC ケモカ イン， CXC ケモカイン，Cケモカイン， CX3C ケ モカインに分類されている ${ }^{8)}$. ケモカイン受容体は $\mathrm{G}$ タンパク質共役型受容体と呼ばれるものの一つ で， CCR， CXCR，XCR， CX3CR に分類され る.ケモカインと受容体の相互作用は，生理的な状 態あるいは炎症状態に打いて細胞の遊走や生存に重 要である.ケモカイン受容体は特定のリンパ球サブ セットを同定するのに有用であったり，ウイルスが 標的細胞に感染する際に必須であったりする等，現 在もっとも注目されている研究分野の一つである. ケモカイン及びその受容体の発現は蔵器や細胞に特 異的であり, 藏器特異的な疾患の解明に重要であ る、これまでに皮膚のリンパ腫の病態と関連してい ると報告されているケモカインを，表 2 にまとめ た ${ }^{9)}$.これらのケモカインについて以下に述べるこ ととする。 


\section{皮膚リンパ腫はなぜ B 細胞が少ないのか}

悪性リンパ腫は臓器ごとに発症しやすい組織型が 存在する. 皮膚の悪性リンパ腫は菌状息肉症に代表 される $\mathrm{T}$ 細胞リンパ腫がその大部分を占める。そ の理由の一つとして皮膚で発現しているケモカイン は, リンパ球のうち $\mathrm{T}$ 細胞の遊走を促すものが 多いことが挙げられる. B 細胞の遊走を促す代表的 なケモカインとしては CXCL13 があり, B lymphocyte chemoattractant (BLC) とも呼ばれる10). CXCR5 がその受容体であり, B 細胞や一部の $\mathrm{T}$ 細 胞に発現している11). 健常皮膚にはこのケモカイン は発現して抢らず，アトピー性皮膚炎や皮膚 $\mathrm{T}$ 細 胞リンパ腫など $\mathrm{T}$ 細胞が皮膚に浸潤する病気にお いても，病変部皮膚に CXCL13 は発現していない。

CXCL13 の主たる産生細胞は濾胞樹状細胞（follicular dendritic cells; FDC) であり, 表皮角化細 胞, 線維芽細胞, 真皮血管内皮細胞などの皮膚に常 在する細胞はこのケモカインを発現しないため, 皮 膚を主座とする疾患では B 細胞の浸潤が少ないと 考えられる。一方, 皮膚で濾胞構造を形成する疾 患, 例えば木村氏病や MALT リンパ腫などでは, 真皮の濾胞中心に CXCL13 が発現しており, B 細 胞が皮膚に浸潤するメカニズムの一つと考えられ る ${ }^{12)}$ 。これらの疾患では，皮膚の濾胞中心に CD21 陽性の濾胞樹状細胞が存在し, CXCL13 のソース となっている(図 1).

近年, 血管免疫芽球型 $\mathrm{T}$ 細胞リンパ腫や原発性 皮膚 CD4 陽性小・中細胞型 $\mathrm{T}$ 細胞リンパ腫の腫瘍 細胞は, 濾胞ヘルパー $\mathrm{T}$ 細胞 (follicular helper $\mathrm{T}$

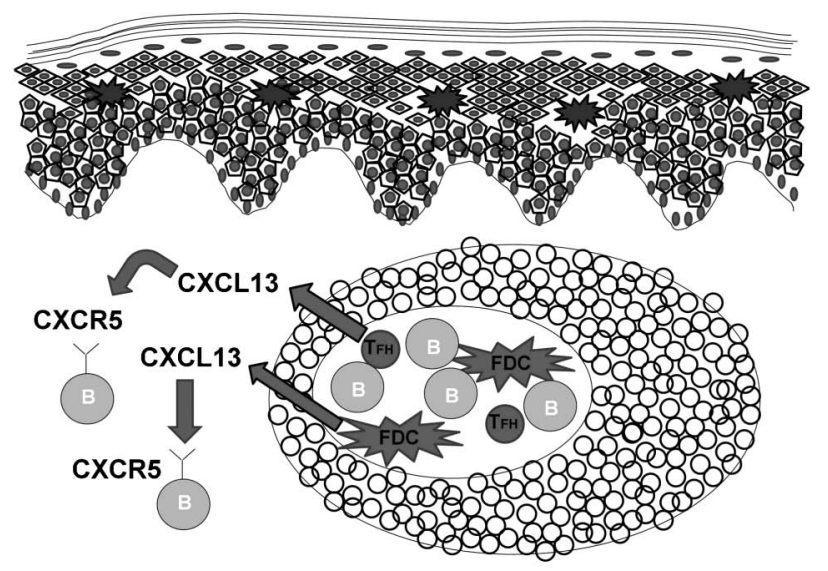

図 1 皮膚に B 細胞が浸潤するメカニズム 真皮内の濾胞樹状細胞 (FDC) と濾胞ヘルパー $\mathrm{T}$ 細胞 (TFH) から CXCL13 が産生され，CXCR5 陽性の B 細胞を 引き寄せる
cells；TFH）の表面抗原を発現していることが報告 されている13). 濾胞へルパー $\mathrm{T}$ 細胞も, 濾胞樹状 細胞と同様にCXCL13 を発現することが知られて いるが，上記のリンパ腫では腫瘍細胞である $\mathrm{T}$ 細 胞の他, 多くの B 細胞が浸潤してくることが知ら れている。一部の症例では B 細胞リンパ腫が続発 することもあり， CXCL13 を発現している $\mathrm{T}$ 細胞 リンパ腫では，B 細胞リンパ腫の続発に気をつけな くてはならない。

\section{皮膚 $\mathbf{T}$ 細胞リンパ腫の表皮向性のメカニズム}

菌状息肉症（mycosis fungoides, MF）及びセザ リ一症候群（Sezary syndrome, SS）は皮膚に親和 性の強い $\mathrm{T}$ 細胞による腫瘍性疾患である. 発症年 齢は成人〜高齢者に多いが，若年者の発症も報告さ れている. 紅斑期, 扁平浸潤期, 腫瘤期と数年から 十年以上かけて進行していく1). 紅斑期に抢いて は, 浸潤細胞はしばしば組織学的に表皮向性を示 し，診断の決め手になることが多い，表皮内に浸潤 している細胞の大部分は, ケモカイン受容体 CXCR3 を発現している 細胞やランゲルハンス細胞がそのリガンドである CXCL9，CXCL10 を発現している14,18,19). CXCL9 は monokine induced by interferon- $\gamma$ (Mig), CXCL10 は interferon-inducible protein-10 (IP10）とも呼ばれ，いずれも IFN- $\gamma$ によって誘導さ れるケモカインである. 表皮角化細胞, ランゲルハ ンス細胞からのCXCL9, CXCL10 と浸潤細胞が発 現するCXCR3 の相互作用が，表皮向性に関与して いると考えられている（図2）。表皮向性を示さな い T 細胞リンパ腫や腫瘤期になって表皮に浸潤し

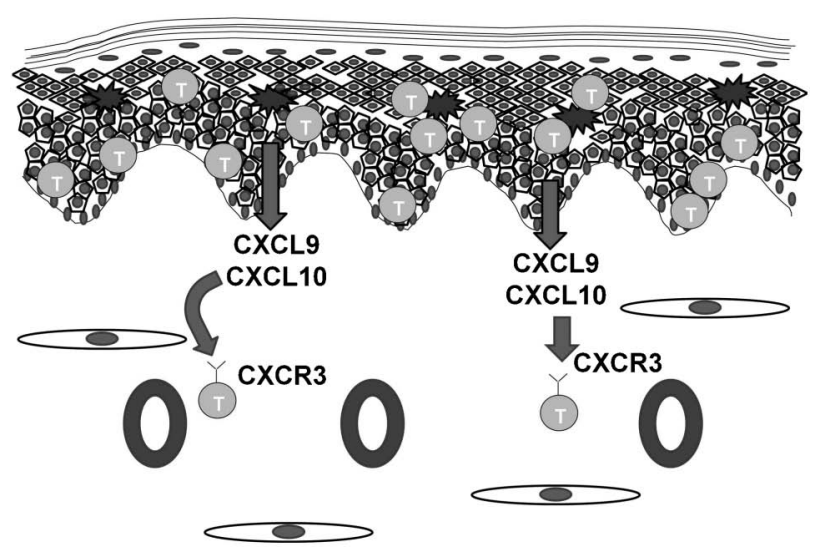

図 2 表皮向性のメカニズム

表皮角化細胞から CXCL9, CXCL10 が産生され, CXCR3 陽性 T 細胞の表皮内浸潤を促す 
なくなると, 腫瘍細胞が CXCR3 を発現しないこと が報告されている2,3.

\section{菌状息肉症/セザリー症候群の病期の進行と ケモカイン受容体}

菌状息肉症の病初期では病変部の細胞の多くは CXCR3 を発現しているが，腫瘤期になるとCCR4 を発現する細胞が主体になってくる2 4)．またセザ リ一症候群，未分化大細胞リンパ腫（anaplastic large cell lymphoma, ALCL), 成人 $\mathrm{T}$ 細胞リンパ腫 では腫瘍細胞が CCR4 を発現することが報告され ている(図 3 $)^{2,4,5,20,21)}$. CCR4 を発現している皮膚 $\mathrm{T}$ 細胞リンパ腫は一般に予後が悪いと考えられる.

後述するようにCCR4のリガンドであるCCL17 (別名 thymus and activation-regulated chemokine; TARC）は皮膚で高度に発現して打り，CCL17 と CCR4 の相互作用は皮膚を主座とするリンパ腫の病 態に重要な役割を果たしていると思われる（図4).

また, ケモカイン受容体 CCR10 も菌状息肉症 の腫瘤期やセザリー症候群の腫瘍細胞が発現して

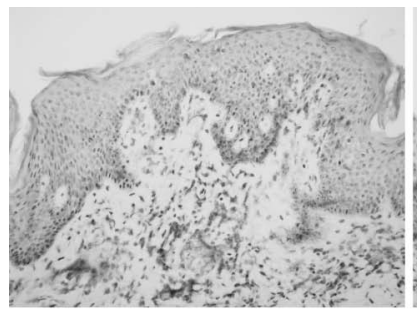

CXCR3

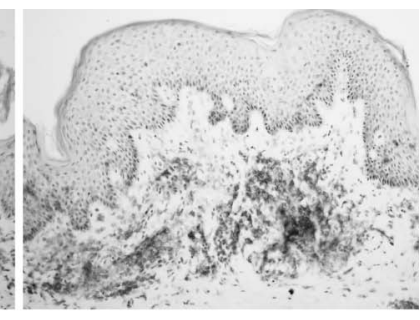

CCR4
図 3 セザリ一症候群における CXCR3, CCR4の発現 セザリ一症候群の病変皮膚に捛いて, 腫瘍細胞の大部分は CXCR3 陰性（左）で，CCR4 真皮陽性（右）である

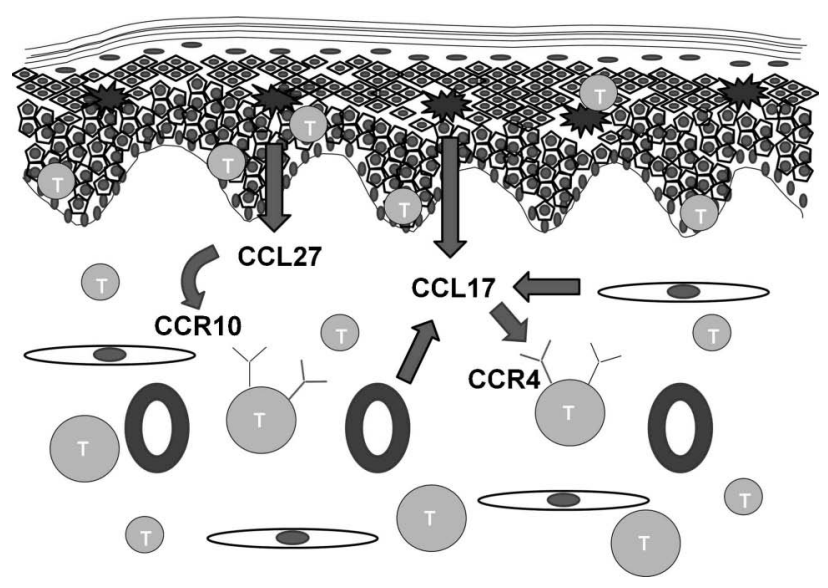

図 4 皮膚 $\mathrm{T}$ 細胞リンパ腫進行期におけるケモカイン受容体 の発現

皮膚に浸潤してくる腫瘍細胞はCCL17 の受容体である CCR4，CCL27 の受容体である CCR10を発現しており，リ ンパ腫が皮膚に親和性がある原因となっていると考えられる
いると報告されている5 7). CCR10 のリガンド である CCL27（別名 cutaneous T cell-attracting chemokine; CTACK）は表皮角化細胞に特異的に 発現しており，CCL27 とCCR10の相互作用が皮 膚における腫瘍細胞の生存に密接に関係していると 考えられている (図 4). 実際,メラノーマ細胞を 用いた研究では, CCL27 とCCR10の相互作用に よって Akt がリン酸化し, 細胞のアポトーシスを 抑制する効果があることが判明している22).しか し，末梢血中の CLA 陽性細胞の多くが CCR 10 陽 性であるのに対し，皮膚に浸潤しているリンパ球の 全てがCCR10 陽性という訳でない，CLA，CCR4， CCR10 やその他の細胞表面分子が，複合的に皮膚 へのリンパ球浸潤に関与していると考えられる.

さらに，ケモカイン受容体 CXCR4 も菌状息肉症 の腫瘤期やセザリ一症候群の腫瘍細胞が発現してい ると報告されている16,23)。CXCR4のリガンドは CXCL12 (別名 stromal cell-derived factor 1, SDF1）であり，皮膚に豊富に発現している。CXCL12 と CXCR4 の相互作用によって CD26の発現が抑制 されることが報告されているが23), CD26の発現低 下は菌状息肉症やセザリ一症候群の腫瘍細胞の特徵 であり, 病態を考える上で興味深い。

\section{病勢を反映するケモカインの血清中濃度}

皮膚のリンパ腫が悪化する場合，通常は皮膚にお ける腫瘍の数が増えたり, 大きさが大きくなったり するため, 病勢の把握は比較的容易である. しか し，腫瘍細胞が皮膚向性を失い，リンパ節や内臓へ 浸潤するような病期になると，皮疹は必ずしも病勢 を反映しなくなる，悪性リンパ腫の病勢を反映する 血清中のマーカーとしては, 乳酸脱水素酵素 $(\mathrm{LDH})$, 可溶化インターロイキン 2 受容体 $(\mathrm{sIL}-$ 2R）が知られている。しかしこれらのマーカーは 感染症などでも非特異的に上昇する。我々はこれま で皮膚のリンパ腫，とりわけ菌状息肉症・セザリー 症候群の患者の血清を用い, 病勢を反映するケモ力 インの検索を行ってきた.CCL17 及び CCL27 は皮 膚に常在する細胞が強く発現するケモカインであ り, 前者は樹状細胞, 線維芽細胞, 血管内皮細胞な どが産生し，後者は表皮角化細胞が主に産生する. これらのケモカインがアトピー性皮膚炎患者の血清 で上昇しており，病勢を反映していることを我々の 教室で報告したが24,25), 菌状息肉症患者の血清にお いも，CCL17 及び CCL27 濃度は健常人と比べて上 


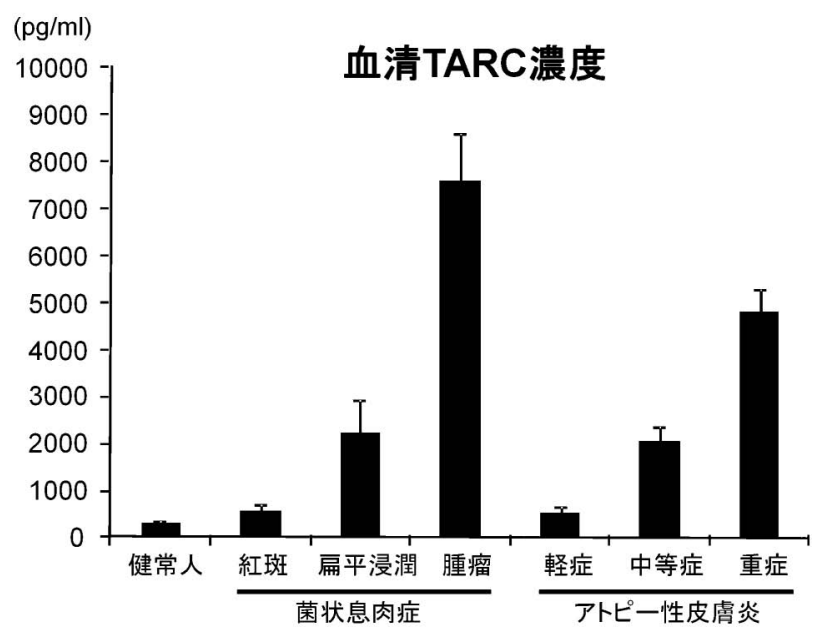

図 5 菌状息肉症, アトピー性皮膚炎患者に打ける血清中 CCL17 濃度

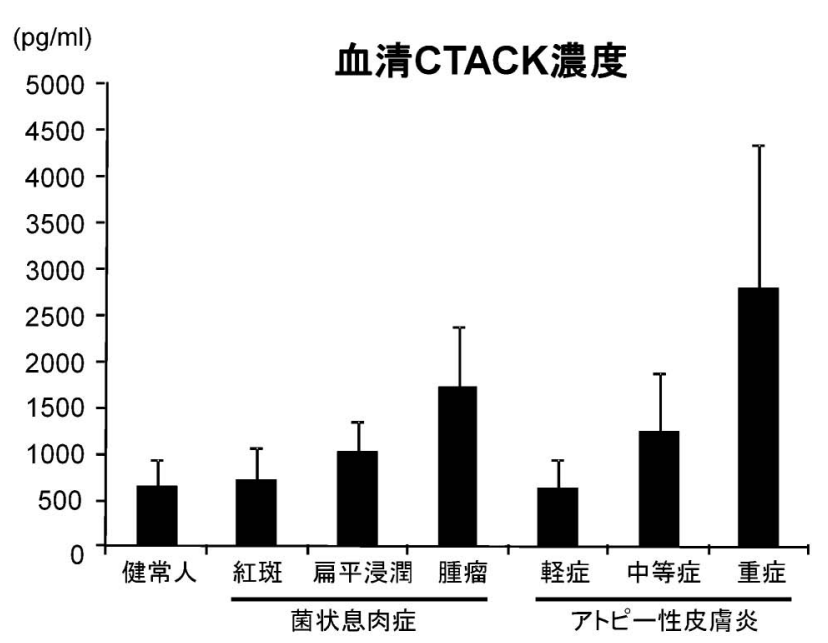

図 6 菌状息肉症, アトピー性皮膚炎患者に抢ける血清中 CCL27 濃度

昇しており，腫瘤期では紅斑期，扁平浸潤期と比べ て有意に高加た（図 5, 6) ${ }^{3,26}$. さらにCCL17, CCL27 は LDH や sIL-2R とよく相関しており，血 清中の病勢マーカーとして使用できることが示され た3,26,27). 興味深いことに, 病期の進んだ菌状息肉 症患者に抢けるこれらのケモカインの值は, 重症の アトピー性皮膚炎患者の值と同程度の高いレベルを 示している (図 5, 6 $)^{3,24 \sim 26)}$. 菌状息肉症とアト ピー性皮膚炎は落屑性紅斑や表面の細菌感染といっ た臨床上類似の特徵を有しており，それらの背景に 同じケモカインが関与している可能性が考えられて 非常に興味深い。

\section{Th2 優位な環境を形成するメカニズム}

菌状息肉症・セザリ一症候群の患者では末梢血中 の好酸球や IgE が高值を示すことがあり, 皮膚病

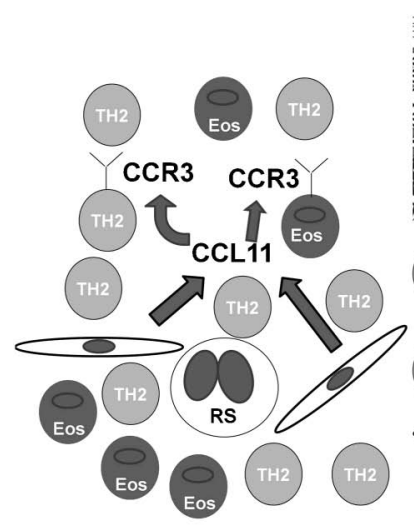

Hodgkin lymphoma

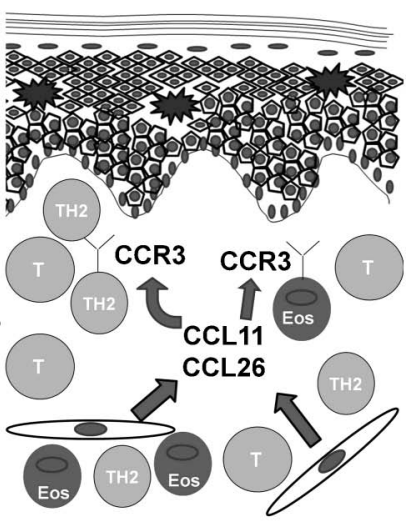

MF/SS
図 7 Th2 優位な環境を形成するメカニズム ホジキン病 (左), 菌状息肉症 $(\mathrm{MF}) /$ セザリ一症候群 (SS) に打いて腫瘍細胞の周囲の線維芽細胞が CCL11, CCL26 を放出し, CCR3 陽性の Th2 細胞や好酸球の遊走を 促す

変部においても全身的にも Th2 優位な状態である と考えられている28). 実際に Th1 系の代表的サイ トカインであるインターフェロン $\gamma$ が，皮膚 $\mathrm{T}$ 細 胞リンパ腫に有効であることは広く知られてい る29). また皮膚 $\mathrm{T}$ 細胞リンパ腫の患者が細菌感染 症を併発すると，全身の Th1 が活性化され，皮膚 病変が一過性に軽快することもよく知られている。 好酸球や Th2 細胞が病变に多く存在するホジキン 病では, 局所の線維芽細胞が CCL11 (別名 eotaxin1）を産生し, CCR3 陽性の好酸球や Th2 細胞が病 変部に浸潤してくると言われている30,31)。我々は菌 状息肉症の病変部に抢いて CCL11，CCL26（別名 eotaxin-3）の発現が上昇しており，病変部由来の 線維芽細胞が，正常皮膚由来の線維芽細胞よりも CCL11，CCL26をより多く産生することを示し た ${ }^{32)}$. さらに血清中 CCL11，CCL26 も正常人と比 べて上昇しており, 病勢マーカーとして有用である ことも判明した．菌状息肉症・セザリ一症候群の腫 瘍細胞は CCR3 を発現していないが，病变部には CCR3 陽性リンパ球が浸潤してきており，ホジキン 病と同様に線維芽細胞から放出された CCL11, CCL26 が局所における Th2 優位の環境を形成する のに重要な役割を果たしていると考えられる(図 7).

\section{CD30 陽性リンパ増殖症における CCR3 の発現}

原発性皮膚 CD30 陽性リンパ増殖症は，原発性皮 膚未分化大細胞リンパ腫 (ALCL) とリンパ腫様丘 疹症 (lymphomatoid papulosis, LyP), 及びそれら の中間型から成る ${ }^{1)}$. 原発性皮膚未分化大細胞リン 


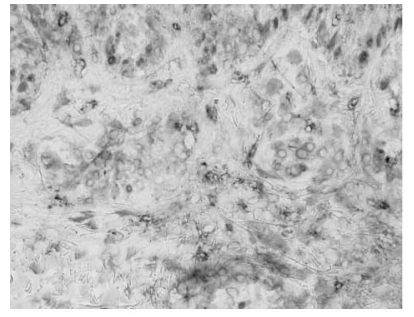

LyP

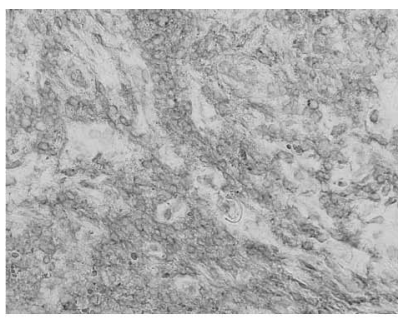

ALCL
図 $8 \mathrm{CD} 30$ 陽性リンパ増殖症における CCR3 の発現 リンパ腫様丘疹症 (LyP) では CCR3 陽性細胞が散在して 抢り（左），未分化大細胞リンパ腫（ALCL）ではほぼ全て の腫瘍細胞が CCR3 陽性である（右）

パ腫とリンパ腫様丘疹症は時に鑑別が難しいことが あること，稀ではあるが移行例の報告があることか ら，両者をまとめてこのように呼んでいる．本邦に おける原発性皮膚覀性リンパ腫の中では，菌状息肉 症，成人 $\mathrm{T}$ 細胞リンパ腫に次ぐ頻度であり，全体 の約 1 割を占める ${ }^{33)}$. 未分化大細胞リンパ腫の腫瘍 細胞は CCR3 を発現していることが報告されてい るが20,34)，リンパ腫様丘疹症の一部の症例に打いて も CCR3 陽性細胞が散在性に認められる（図 8). 前述のように皮膚の線維芽細胞が CCL11, CCL26 を産生することから，CCL11，CCL26 と CCR3の 相互作用が病態形成に関与していることが考えられ る.さらに未分化大細胞リンパ腫の腫瘍細胞自身が CCL11を産生することも報告されて抢り ${ }^{34)}$ ， CCL11 はパラクラインとしてだけでなく，オート クラインとして働く可能性が考えられる. 実際我々 は, CCL11 が CCR3 陽性リンパ腫細胞の MAPK/ ERK 経路を活性化し，生存・増殖を促すことを明 らかにした（投稿中）.

\section{リンパ節転移の背景にあるもの}

CCR7 は CCL21 (別名 secondary lymphoid-tissue chemokine, SLC) の受容体であり, リンパ球や 樹状細胞がリンパ節へ遊走するのに重要であ る35,36). リンパ節腫脹が特徵であるセザリ一症候群 では腫瘍細胞が CCR7 を発現することが報告され ている ${ }^{5,6)}$. また菌状息肉症の腫瘤期の細胞でも CCR7 の発現が報告されている16). CCR7 は他の癌 でもリンパ節転移の鍵となる受容体であり, 皮膚 $\mathrm{T}$ 細胞リンパ腫においてもリンパ節転移への関与が考 えられる。

\section{今後の展望}

皮膚のリンパ腫，特に菌状息肉症・セザリ一症候
群においては，表皮向性や病期にともなう腫瘍細胞 の性質の変化などがケモカインによってかなり説明 可能になってきた．今後はケモカインの腫瘍細胞に 対する影響がより深く解明され，ケモカインやその 受容体に対する抗体を用いた治療が臨床応用される ことが期待される．実際，菌状息肉症/セザリ一症 候群の腫瘍細胞に発現しているCCR4 を標的にし た抗体療法が現在治験中である．少なくともマウス の実験では非常によい成績を出しており，効果が期 待される ${ }^{37,38)}$. B 細胞リンパ腫にお打抗 CD20 抗 体と同じように臨床の現場で用いられる日も近いと 思われる。また，CCR4 はアレルギーの主役である Th2 細胞に発現しているため，喘息，花粉症などに 対しても臨床応用が検討されている. 菌状息肉症 · セザリー症候群とアレルギー性疾患で共通の治療戦 略を用いることができるのは，非常に興味深い，注 意しないといけないのは，血清中のケモカイン濃度 や皮膚に浸潤する細胞の発現するケモカイン受容体 が類似していても, 腫瘍性疾患である菌状息肉症 . セザリー症候群とアレルギー性疾患であるアトピー 性皮膚炎は全く別であるということである。これら の疾患は決して混同してはならないし，またアト ピー性皮膚炎が皮膚悪性リンパ腫の前段階であるよ うな䛊った解釈はいたずらに患者の不安をあ打るた けである、今後のさらなる研究によって，これらの 疾患も新たなケモカインや受容体によって鑑別でき るようになるかもしれない。

\section{文献}

1) Swerdlow, S. H., et al. : WHO Classification of Tumours of Haematopoietic and Lymphoid Tissues. Ed. IARC Press, Lyon, 299, 2008.

2) Yagi, H., et al. : Chemokine receptor expression in cutaneous $\mathrm{T}$ cell and NK/T-cell lymphomas: immunohistochemical staining and in vitro chemotactic assay. Am J Surg Pathol 30 : 1111-1119, 2006.

3) Kakinuma, T., et al. : Thymus and activationregulated chemokine (TARC/CCL17) in mycosis fungoides : serum TARC levels reflect the disease activity of mycosis fungoides. $\mathrm{J} \mathrm{Am}$ Acad Dermatol, 48 : 23-30, 2003.

4) Ferenczi, K., et al. : Increased CCR4 expression in cutaneous $\mathrm{T}$ cell lymphoma. $J$ Invest Dermatol 119 : 1405-1410, 2002.

5) Sokolowska-Wojdylo, M., et al. : Circulating clonal CLA $(+)$ and CD4 $(+)$ T cells in Sézary 
syndrome express the skin-homing chemokine receptors CCR4 and CCR10 as well as the lymph node-homing chemokine receptor CCR7. $\mathrm{Br}$ J Dermatol 152 : 258-264, 2005.

6) Capriotti, E., et al. : Chemokine receptor expression by leukemic $\mathrm{T}$ cells of cutaneous $\mathrm{T}-$ cell lymphoma : clinical and histopathological correlations. J Invest Dermatol 127 : 2882-2892, 2007.

7) Fujita, Y., et al. : Presence of Circulating CCR10 + T cells and Elevated Serum CTACK/ CCL27 in the Early Stage of Mycosis Fungoides. Clin Cancer Res 12 : 2670-2675, 2006.

8) Yoshie, O., et al. : Chemokines in immunity. Adv Immunol 78 : 57-110, 2001.

9) Sugaya, M. : Chemokines and cutaneous lymphoma. J Dermatol Sci 59 : 81-89, 2010.

10) Legler, D. F., et al. : B cell-attracting chemokine 1, a human CXC chemokine expressed in lymphoid tissue, selectively attracts B lymphocytes via BLR1/CXCR5. J Exp Med 187 : 655-660, 1998.

11) Forster, R., et al. : Expression of the G-protein-coupled receptor BLR1 defines mature, recirculating $B$ cells and a subset of T-helper memory cells. Blood 84 : 830-840, 1994.

12) Ohmatsu, H., et al. : CXCL13 and CCL21 are expressed in ectopic lymphoid follicles in cutaneous lymphoproliferative disorders. $J$ Invest Dermatol 127 : 2466-2468, 2007.

13) Rodr?guez-Pinilla, S. M., et al. : Primary cutaneous $\mathrm{CD} 4+$ small/medium-sized pleomorphic T-cell lymphoma expresses follicular T-cell markers. Am J Surg Pathol 33 : 81-90, 2009.

14) Sarris, A. H., et al. : Cytokine loops involving interferon-gamma and IP-10, a cytokine chemotactic for $\mathrm{CD} 4+$ lymphocytes : an explanation for the epidermotropism of cutaneous T-cell lymphoma? Blood 86 : 651-658, 1995.

15) Lu, D., et al. : The T-cell chemokine receptor CXCR3 is expressed highly in low-grade mycosis fungoides. Am J Clin Pathol 115 : 413-421, 2001.

16) Kallinich, T., et al. : Chemokine receptor expression on neoplastic and reactive $\mathrm{T}$ cells in the skin at different stages of mycosis fungoides. J Invest Dermatol 121 : 1045-1052, 2003.

17) Yamaguchi, T., et al. : The comparison of expression of cutaneous lymphocyte-associated antigen (CLA), and Th1- and Th2-associated antigens in mycosis fungoides and cutaneous lesions of adult $\mathrm{T}$-cell leukemia/lymphoma. Eur J Dermatol 13 : 553-559, 2003.

18) Sarris, A. H., et al. : Interferon-inducible protein 10 as a possible factor in the pathogenesis of cutaneous T-cell lymphomas. Clin Cancer Res 3 : 169-177, 1997.

19) Tensen, C. P., et al. : Epidermal interferongamma inducible protein-10 (IP-10) and monokine induced by gamma-interferon (Mig) but not IL-8 mRNA expression is associated with epidermotropism in cutaneous $\mathrm{T}$ cell lymphomas. J Invest Dermatol $111: 222-226$, 1998.

20) Yamaguchi, T., et al. : Expression of chemokines and chemokine receptors in cutaneous CD30+ lymphoproliferative disorders. $\mathrm{Br}$ J Dermatol, 154 : 904-909, 2006.

21) Yoshie, O., et al. : Frequent expression of CCR4 in adult T-cell leukemia and human Tcell leukemia virus type 1-transformed $\mathrm{T}$ cells. Blood, 99 : 1505-1511, 2002.

22) Murakami, T., et al.: Immune evasion by murine melanoma mediated through CC chemokine receptor-10. J Exp Med 198 : 13371347, 2003.

23) Narducci, M. G., et al. : Skin homing of Sézary cells involves SDF-1-CXCR4 signaling and down-regulation of $\mathrm{CD} 26 /$ dipeptidylpeptidase IV. Blood 107 : 1108-1115, 2006.

24) Kakinuma, T., et al. : Thymus and activationregulated chemokine in atopic dermatitis: Serum thymus and activation-regulated chemokine level is closely related with disease activity. J Allergy Clin Immunol 107 : 535-541, 2001.

25) Kakinuma, T., et al. : Increased serum cutaneous $\mathrm{T}$ cell-attracting chemokine (CCL27) levels in patients with atopic dermatitis and psoriasis vulgaris. J Allergy Clin Immunol 111 : 592-597, 2003.

26) Kagami, S., et al. : Elevated serum CTACK/ CCL27 levels in CTCL. J Invest Dermatol, 126 : 1189-1191, 2006.

27) Masui, Y., et al. : Sézary syndrome treated with narrowband ultraviolet $\mathrm{B}$ : time-course measurement of serum levels of CCL17/CCL27. Clin Exp Dermatol 32 : 57-59, 2007.

28) Vowels, B. R., et al. : Th2 cytokine mRNA expression in skin in cutaneous T-cell lymphoma. J Invest Dermatol 103 : 669-673, 1994. 
29) Kaplan, E. H., et al. : Phase II study of recombinant human interferon gamma for treatment of cutaneous T-cell lymphoma. J Natl Cancer Inst 82 : 208-212, 1990.

30) Teruya-Feldstein, J., et al. : Differential chemokine expression in tissues involved by Hodgkin's disease : direct correlation of eotaxin expression and tissue eosinophilia. Blood 93 : 2463-2470, 1999.

31) Jundt, F., et al. : Hodgkin/Reed-Sternberg cells induce fibroblasts to secrete eotaxin, a potent chemoattractant for $\mathrm{T}$ cells and eosinophils. Blood 94 : 2065-2071, 1999.

32) Miyagaki, T., et al. : Eotaxins and CCR3 Interaction Regulates Th2 Environment of Cutaneous T Cell Lymphoma. J Invest Dermatol 130 : 2304-2311, 2010.

33) Hamada, T.: A 2008 nationwide survey on cutaneous lymphomas. Skin Cancer $24: 192-$ 198, 2009.

34) Kleinhans, M., et al. : Functional expression of the eotaxin receptor CCR3 in CD30+ cutane- ous T-cell lymphoma. Blood 101 : 1487-1493, 2003.

35) Gunn, M. D., et al. : Mice lacking expression of secondary lymphoid organ chemokine have defects in lymphocyte homing and dendritic cell localization. J Exp Med 189 : 451-460, 1999.

36) Saeki, H., et al. : Cutting edge : secondary lymphoid-tissue chemokine (SLC) and CC chemokine receptor 7 (CCR7) participate in the emigration pathway of mature dendritic cells from the skin to regional lymph nodes. J Immunol 162 : 2472-2475, 1999.

37) Ishida, T., et al. : The CC chemokine receptor 4 as a novel specific molecular target for immunotherapy in adult T-cell leukemia/lymphoma. Clin Cancer Res 10 : 7529-7539, 2004.

38) Yano, H., et al. : Defucosylated anti CC chemokine receptor 4 monoclonal antibody combined with immunomodulatory cytokines : a novel immunotherapy for aggressive/refractory Mycosis fungoides and Sézary syndrome. Clin Cancer Res 13 : 6494-6500, 2007. 